\title{
A Case Study on Narcissism and Anxiety amongst Students
}

\author{
Erlinda P. Jumag ${ }^{1 \#}$ \& Jerald C. Moneva ${ }^{2}$ \\ ${ }^{1,2}$ Jagobiao National High School, Jagobiao, Mandaue City, Cebu, Philippines. \\ \#corresponding author \\ Type of Work: Peer-Reviewed \\ DOl: http://dx.doi.org/10.21013/jems.v16.n1.pg
}

\section{How to cite this paper:}

Jumag, E.P., Moneva, J.C. (2020). A Case Study on Narcissism and Anxiety amongst Students. IRA International Journal of Education and Multidisciplinary Studies (ISSN 2455-2526), 16(1), 59-67. doi: http://dx.doi.org/10.21013/jems.v16.n1.pg

(C) Institute of Research Advances.

This work is licensed under a Creative Commons Attribution-Non Commercial 4.0 International License subject to a proper citation to the publication source of the work.

Disclaimer: The scholarly papers as reviewed and published by the Institute of Research Advances (IRA) are the views and opinions of their respective authors and are not the views or opinions of the IRA. The IRA disclaims of any harm or loss caused due to the published content to any party.

Institute of Research Advances is an institutional publisher member of Publishers International Linking Association Inc. (PILA-CrossRef), USA. The institute is an institutional signatory to the Budapest Open Access Initiative. Hungary advocating the open-access of scientific and scholarly knowledge. The Institute is a registered content provider under Open Access Initiative Protocol for Metadata Harvesting (OAl-PMH).

The journal is indexed \& included in WorldCat Discovery Service (USA), CrossRef Metadata Search (USA), WorldCat (USA), OCLC (USA), Open J-Gate (India), EZB (Germany) Scilit (Switzerland), Airiti (China), Bielefeld Academic Search Engine (BASE) of Bielefeld University, Germany, PKP Index of Simon Fraser University, Canada. 


\begin{abstract}
The study intends to assess the level of the narcissism of students and the level of anxiety. Narcissism is an excessive admiration and unrealistic positive view of oneself and physical appearance. While anxiety is a feeling of having fear of what might happen that is usually experienced by the students. The study is anchored in the Cognitive Development Theory of Jean Piaget in 1936. He explained anxiety as the tendency to overestimate the potential for danger. This research study used the correlational quantitative design because it examined the association between the level of the narcissism of students and the level of anxiety. Using a rating scale questionnaire on the level of narcissism and the level of anxiety is the level of anxiety among senior high school students. The researchers found out that most of the students feel assertive. Also, they seldom like to be the center of attention which means of having a narcissistic personality which could affect the way they perform in school. Meanwhile, they also feel anxious of hearing the announcement of a coming test and reading the first question on final exam. The data gathered was treated with the use of statistical tests the weighted mean and chisquare. The study showed that there is an association between the level of narcissism and level of anxiety.
\end{abstract}

\title{
INTRODUCTION
}

Keywords: Narcissism, Anxiety, Students

Narcissism is an excessive admiration and unrealistic positive view of oneself and physical appearance. A student who has moderate anxiety triggered themselves to work hard in school [1].

Students who recognized themselves a superior among others have a narcissistic personality which generally unhappy and disappointed when they don't get what they want. This may affect their performance and relationship with others. They may find relationships unfulfilling and others may not enjoy being with them. A narcissist has a connection regarding the academic achievement, attitude, and behavior of a person [2]. An individual who lives in an unrealistic belief that they can do better than others like a student who meanwhile performance has a narcissistic personality [3].It students may feel anxiety and apprehension about having a fear of what might happen. It will become a problem when a student consistently feels worries and fears as it distract their concentration in learning. This is usually experienced by a student who doesn't believe of what they can do. They just seem to think about negative thoughts instead of cheering themselves to have a good performance. Anxiety triggered the students to become irresponsible they may not focus on school works and activities that were tasked to do. Aside from that apprehension also affect the student confidence especially if they have the talents and skills. They cant show their abilities totally because of the fear. Furthermore, it is normal for a person to feel this kind of feeling but it will become a problem if he or she cannot control this, it will cause a negative impact on their lives.

The study would like to determine the correlation between narcissistic students and anxiety. The researcher also wants to know the students' feelings towards their studies.

\section{STATEMENT OF PURPOSE}

The study intends to assess the correlation between narcissistic students and anxiety. In particular, the study seeks to answer the following: To what extent do students manifest narcissism? What is the level of anxiety on students? Is there an association between the extent of narcissism students and the level of anxiety?

\section{Hypothesis}

H0: There is no association between narcissistic students and anxiety.

H1: There is an association between narcissistic students and anxiety. 


\section{REVIEW OF RELATED LITERATURE}

The higher level of narcissism does not directly affect academic but in the relationship [2]. A narcissist individual with higher self-perceived think his or her work as the best [3]. The same behaviors with good reactions could drive narcissists to suffer long term consequences in the interpersonal [4]. Narcissists are motivated to achieve extrinsic goals for it is valuable for them, but it also lessens their satisfaction in lives [5]. Relationship satisfaction decreases and positive love perception increases because of narcissistic traits [6]. Severe narcissistic organization concentrate only on its own fear that it won't be able to express without a purpose [7]. Narcissistic does not have connections on age, income level and even gender [8]. When students have a high level of narcissism they will experience a high negative experience [9]. Narcissism entails positive outcomes in academic performance [10]. However, identification of narcissistic includes on the team can develop for a better group output [11]. Millennials are now using social media not just for personal relations, but also they're idealized [12]. A person who was known a narcissist for a short time would see narcissist as positive compared to those who are narcissist for a long time [13]. Narcissistic admiration has a better outcome with prestige-based as it involves self-improvements [14]. The career enhancement of a narcissist is not true to career development it is because narcissist people think of themselves as a success [15]. Those people with a high level of narcissism think their ability is high but in reality, is low [16].

Many researchers discover that there are different sources of student's anxiety that affect their performance in school [17]. Test anxiety is beneficial for some students but others find it bad on health and performance [18]. Test anxiety also lowers the ability of students to achieve better outcomes which leads to failure [19]. Higher anxiety may suffer that affects the mind and body [20]. While, moderate level of anxiety is important in student's life as it help to strive their goals [21]. Academic stress, financial, peer and family support are counted of the variance of collegiate anxiety [22]. Hence, teachers can help students in their difficulties to lessen anxiety [23]. Students should know about anxiety for them to be aware and manage their selves wherever they are [24]. When students have a high level of cognitive anxiety their academic performance will decrease [25]. Severe state anxiety will become a reason for the failures of students academically [26]. Teachers should implement good study for students to prevent high test anxiety [27]. Although it is normal for a student to feel moderate anxiety especially in a particular subject sometimes it would be a factor that affects their studies [28]. The decrease in anxiety enhances the students through success and will feel good [29]. Academic anxiety negatively affects the way the students perform in activities [30]. High cognitive test anxiety affects the learning process of students [31].

\section{METHODOLOGY}

\section{Environment}

The study was conducted at a certain school in Mandaue City, Cebu Philippines.

\section{Respondent}

Out of 249 , there are 240 who answered senior high school students.

\section{Design}

This research study used the correlational quantitative design because it examined the relationship between the extent of narcissism students and anxiety.

\section{Instrument}

The researcher made a survey questionnaire that consists of two parts first is the narcissistic students and the second is anxiety. questionnaire for there extent of narcissism has 1-10 respondents would rate 1-4, for the narcissistic personality of the students 1 -never,2 seldom,3 and 4-always and for the anxiety, it is answerable 1-not at all, 2-a little,3 a fair amount,4-much and 5-very much. 


\section{Data Gathering Procedure}

The researcher made a transmittal letter signed by the principal and teacher approval. The researcher can directly conduct the survey questionnaire and it will be distributed to the respondents. The information gathered by the researcher will be the basis in making the analysis, findings, conclusions, and recommendations of the study.

\section{Statistical treatment}

The data will be conduct by using the weighted mean and chi-square. It determines the relationship of the two variables which is narcissistic students and anxiety

\section{PRESENTATION, ANALYSIS, AND INTERPRETATION OF DATA}

\section{Table 1}

Narcissistic Students

\begin{tabular}{lcc}
\hline Indicators & $\begin{array}{c}\text { Weighted } \\
\text { Mean }\end{array}$ & Interpretation \\
\hline 1. When people compliment me I sometimes get embarrassed. & 2.73 & Sometimes \\
2. I know that I am good because everybody keeps telling me so. & 2.55 & Sometimes \\
3. I think I am a special person. & 2.53 & Sometimes \\
4. I don`t mind following orders. & 2.53 & Sometimes \\
5. I like having authority over people. & 2.50 & Seldom \\
6. I don`t like it when I find myself manipulating people. & 2.83 & Sometimes \\
7. I find it easy to manipulate people. & 2.37 & Seldom \\
8. I usually get the respect that I deserve. & 2.90 & Sometimes \\
9. I really like to be the center of attention. & 2.21 & Seldom \\
10. I always know what I am doing. & 2.94 & Sometimes \\
\hline \multicolumn{1}{c}{ OVERALL WEIGHTED MEAN } & 2.61 & Sometimes \\
\hline Legend: 1:00-1.75 (Never) 1.76-2.50 (Seldom) 2.51-3.25 (Sometimes) & 3.26-4.00 (Always) &
\end{tabular}

Table 1 reveals the three highest and lowest weighted mean. The highest weighted mean indicates that students sometimes know what they are doing. The second is that students get the respect that they deserve. The third showed that students sometimes don't like seeing themselves manipulating other people. Having a narcissistic personality could affect the way the person thinks of his or her status [16].

However, the lowest weighted mean explains as students seldom like to be the center of attention. The second-lowest revealed that students seldom like having authority over people. The narcissistic can acquire bad behavior [8]. Lastly, it was found out that sometimes students think of a special person and mind of following orders. Narcissism can affect an individual in terms of interpersonal relations [5]. 
Table 2

Narcissism

\begin{tabular}{ccc}
\hline & Frequency & Percent \\
\hline Not Narcissistic & 0 & 0 \\
Less Narcissistic & 15 & 6.2 \\
Fairly Narcissistic & 195 & 80.8 \\
Very Narcissistic & 30 & 12.5 \\
\hline Total & 240 & 100.0 \\
\hline
\end{tabular}

The table shows the percentage of having a narcissistic. Most of the students are having a narcissistic a fairly narcissistic with $80.8 \%$. While some are experiencing a very high narcissistic which is $12.5 \%$. However, $6.2 \%$ of students have less narcissistic and none are not having narcissistic ( 0 ).

Table 3

\begin{tabular}{lll}
\hline Anxiety & Weighted & Interpretation \\
\hline $\begin{array}{l}\text { 1. Going into a regularly scheduled class period in which the } \\
\text { professor asked the student to participate. }\end{array}$ & 3.25 & A fair amount \\
$\begin{array}{l}\text { 2. Reading the answers I give on the test before turning it in. } \\
\text { 3. Sitting down to study before the regularly scheduled class. }\end{array}$ & 3.15 & A fair amount \\
$\begin{array}{l}\text { 4. Turning my complete test paper. } \\
\text { 5. Hearing the announcement of a coming test. }\end{array}$ & 3.27 & A fair amount \\
$\begin{array}{l}\text { 6. Having a test returned. } \\
\text { 7. Reading the first question on a final exam. }\end{array}$ & 3.37 & A fair amount \\
8. Studying for a class in which I am scared of the professor. & 3.26 & A fair amount \\
9. Being in class waiting for my corrected test to be returned. & 3.10 & A fair amount \\
10. Saying a test question and not being sure of the answer. & 3.18 & A fair amount \\
\hline OVERALL WEIGHTED MEAN & 3.20 & A fair amount \\
\hline
\end{tabular}

Table 2 represents the three highest and three lowest weighted means. The highest weighted mean is 3.37 indicator 5 and 7 which is analyzed as "a fair amount of hearing the announcement of a coming test and reading the first question on a final exam." There should be a program implemented regarding anxiety and stress management to help students [22]. The second highest is indicator is 4 with a weighted mean of 3.27 that interpreted as "a fair amount of turning the complete test paper." Students can conquer test anxiety, especially when having a polite strategy in studying [29]. The third highest weighted mean is 3.26 indicator 8 and analyzed as "a fair amount of studying for a class and scared of the professor." Meanwhile, the lowest weighted mean is 3.02 indicator 3 and interpreted as "a fair amount of sitting down to study before the regular scheduled class." The second-lowest weighted mean is 3.10 indicator 9 and interpreted as "a fair amount of being in class waiting for a corrected test paper to be returned." Lastly the third highest weighted mean is 3.15 indicator 2 that revealed "a fair amount of reading the answers before turning it in."Poor performance is caused by test anxiety but it can be coped by the practice of dealing it [30]. 
Table 4

ANXIETY

\begin{tabular}{ccc}
\hline Indicators & Frequency & Percent \\
\hline No Anxiety at All & 2 & .8 \\
Less Anxiety Level & 4 & 1.7 \\
Fair Anxiety Level & 116 & 48.3 \\
Moderate Anxiety Level & 90 & 37.5 \\
High Anxiety Level & 28 & 11.7 \\
\hline Total & 240 & 100.0 \\
\hline
\end{tabular}

Table 4 indicates the frequency and percentage of students according to their anxiety level. On the above ratings, most of the students are having a fair and anxiety level with a percentage of $48.3 \%$ and $37.5 \%$ are some of those who have a moderate level of anxiety. There are $11.7 \%$ of the high level of anxiety of students and $1.7 \%$ with less level of anxiety. However, $8 \%$ of students with no anxiety level at all.

Table 5 CHI SQUARE

\begin{tabular}{|l|r|r|r|}
\hline & \multicolumn{1}{|c|}{ Value } & \multicolumn{1}{c|}{ df } & $\begin{array}{c}\text { Asymp. Sig. (2- } \\
\text { sided) }\end{array}$ \\
\hline Pearson Chi-Square & $8.531 \mathrm{E} 2^{\mathrm{a}}$ & 775 & .026 \\
Likelihood Ratio & 453.037 & 775 & 1.000 \\
Linear-by-Linear & 3.604 & & 1 \\
Association & 240 & & .058 \\
N of Valid Cases & & \\
\hline
\end{tabular}

a. 832 cells $(100.0 \%)$ have expected count less than 5 . The minimum expected count is .00 .

The table above shows that the p-value (.026) is greater than the alpha (.05). Thus, the null hypothesis would be rejected and there is significant association between narcissistic students and anxiety. Students with a high level of anxiety cannot perform academically and they cannot even have a good relationship [26]. The result of the study showed that a higher level of individualism is associated with higher narcissism [9]. Narcissistic people consider themselves as a "socioemotionally" gifted [18].

\section{FINDINGS}

The extent students sometimes know what they are doing. The study revealed that the students got the respect that they deserve. However, they don't like themselves manipulating other people even if it is easy for them to manipulate. Besides, they want to have power over people. They seldom like to be the center of attention because narcissistic students seek attention.

The student's level of anxiety is highly affected in their studies. As a result, they feel anxious about sitting down to study before the regular schedule of the class. They usually experience fear especially on waiting 
for the result of the exam to be returned. This kind of feeling may affect the students the way they perform in school and communicate with their professor.

The study revealed that there is a significant association between the two variables which narcissistic students and anxiety. It can be seen that having a narcissistic personality does not have a connection of feeling anxious.

\section{CONCLUSION}

The study is to determine the association between narcissistic students and anxiety towards academic performance. The narcissistic individual usually acts or shows insulting attitude among others in which they think they are more important and smarter. The result of the study shows that most of the students sometimes feel in a way of living in an unrealistic world. They think of themselves as the best and superior to other people. On the other hand, students also experienced fear or nervousness about what might happen, Anxiety is common among students of education that are caused by not being confident. They tend to think the students lack the concentration of self and also a negative way.

\section{RECOMMENDATIONS}

These are the following recommendations:

Students must be aware of narcissistic personality and anxiety so that their studies would not be affected. They should have the knowledge to control of narcissism and anxiety for them to cope up easily.

Parents should understand and support their children to prevent or lessen their anxiety towards their studies. This could contribute to better outcomes of student's performance in school.

Teachers must teach their students about narcissism and anxiety to gain information about what it may bring to a student`s life.

\section{References}

[1]. Afolayun, J. A., Bitus, D., Olanyinka, O., Adeyanju, B. \& Agama J. (2013).Relationship between anxiety and academic performance of nursing students, Niger Delta Univesity, Bayelsa State,

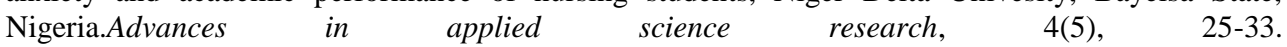
https://www.Inedpub.com/articles/relationship-between-anxiety-and-academicperformanceofnursingstudentsniger-delta,universitybayelsastate-Nigeria.pdf

[2]. Menon, M. K. \&Sharland, A. (2011). Narcissism, exploitative attitudes, and academic dishonesty: an exploratory investigation of reality versus myth. Journal of Education for Business, 86, 51-55. DOI: 10.1080/08832321003774772

[3]. Delima, G., Avelino, B. \&Cuncha, J. (2017). Narcissism are accounting students using their personality traits to perform better. Journal of Accounting and Organizations, 31, 58-74. DOI: https://dx.doi.org/10.v11.737775

[4]. Vasire, S. \& Funder, D.C.( 2006). Impulsivity and the self-defeating behavior of narcissists. Personality and Social Psychology Review, 10(2), 154-165. https://www.researchgate.net/publication/7014226_Impulsivity_and_the_SelfDefeating_Behavior_of_Narcissists

[5]. Abeyta, A., Routlegde, C., \&Sedikides, C. (2017). Material meaning: narcissists gain existential benefits from extrinsic goals.Social Psychological and Personality Science, 8(2). DOI: $10.77 / 19485506116667618$

[6]. Zando, K.W.L. (2012). Narcissism and romantic relationship: the mediating role of perception discrepancy. SS Student E-Journal, 1, 1-20. http://ssweb.cityu.edu.hk/download/RS/EJournal/journal1.pdf

[7]. Duchon, D. \& Drake, B. (2009). Organizational narcissism and virtuous behavior Journal of International Business Studie, 85(30), 301-308. DOI 10.1007/s10551-008-9771-7

[8]. Foster, J. D., Campbell, W. K. \&Twenge, J. M. (2003). Individual differences in narcissism: inflated self-views across the lifespan and around the world. Journal of Research in Personality, 37, 469-486. https://www.researchgate.net/publication/222567676_Individual_differences_in_narcissism_Inflated _self-views_across_the_lifespan_and_around_the_world 
[9]. Li, Z. (2015). The analysis of the influences of student's narcissistic personality traits to negative mentoring experiences.Creative Education, 6, 350-388. http://dx.doi-org/10.4236/ce.2015.63033

[10].Balaji, V. \&Balasundaram, I. (2015). A study on sub-clinical narcissistic personality score and its relationship with academic performance- an Indian experience. Asian Social Science, 11 (2), 96-102. doi:10.5539/ass.v11npa6

[11].Brown, J.,Akers , M.\&Giacomino, D. E. (2013). Narcissism and accounting majors. American Journal of Business Education, 6 (3), 375-384. https://files.eric.ed.gov/fulltext/EJ1054432.pdf

[12].Wickel, T. M. (2015).Narcissism and Social Networking Sites: the act of taking selfies. The Journal of Undergraduate Research in Communications, 6 (1), 5-12. https://www.csus.edu/faculty/m/fred.molitor/docs/selfies\%20and\%20narcissism.pdf

[13].Grijalva, E \&\& Zhang, L. (2015). Narcissism and self-insight: a review and meta-analysis of narcissists' self-enhancement tendencies.Personality and Social Psychology Bulletin, 1-22. DOI: $10.1177 / 0146167215611636$

[14].Zeigler-Hill, V.et al. (2017). Narcissism and the pursuit of status.Journal of Personality, 310-327. DOI:10.1111/jopy.12392

[15].Hirschi, A. \&Jaensch, V. K. (2015). Narcissism and career success: occupational self-efficacy and career engagement as mediators. Personality and Individual Differences, 77, 205-208. https://www.researchgate.net/publication/271224682_Narcissism_and_career_success_Occupational _self-efficacy_and_career_engagement_as_mediators

[16]. Mota, S., et al. (2009). A comprehensive examination of narcissists` and self-perceived and actual socioemotional cognition ability. Collabra: Psychology, 5(1). DOI: https://doi.org/10.1525/collabra.174

[17].Vitsari, P.,Wahab, M. N. A.\&Awang, M.G. (2010). Research for identifying study anxiety sources among university status. International Education Studies, 3 (2) .fies.eric.ed.gov/Fulltext/EJ1066077.pdf

[18].Hamzah, F., Chemat, K., Bhagat, V. \&Mahyiddin, N. (2018). Text anxiety and its impact on firstyear university students and the overview of mind and body intervention to enhance coping skills in facing exams. Research Journal Pharm and Tech, 11(6),22-28. DOI:1O.595810974360X.2018.00411.0

[19]. Yousefi, F. et al. (2010). The relationship between test anxiety and academic achievement among Iranian adolescents.Asian Social Sciences https://www.researchgate.net/publication/43199063_The_Relationship_between_TestAnxiety_and_Academic_Achievement_among_Iranian_Adolescents

[20].Rajiah, K., Coumaravelou, S.\& Ying, O.W. (2014).Relationship of test anxiety, psychological distress and academic motivation among first-year undergraduate pharmacy students. International Journal of Applied Psychology, 14 (2), 68-72.Doi :10.5923/j.ijap.20140402.04

[21].Azeem , M. A. (2018). Study of anxiety and academic achievement among secondary school students.International Journal of Research in Social Sciences, 8 (3), 149-160. https://www.ijmra.us/project\%20doc/2018/IJRSS_MARCH2018/IJMRA-13408.pdf

[22].Jones, P. J., Park, S.Y.\&Lefeyor, G.T.(2018). Contemporary college students anxiety: The role of academic distress, financial stress, and support. American Counseling Association. DOI:10.1002/jock.12107

[23].Mohammadpur, B. \&Ghafournia, N.(2015). An elaboration on the effect of reading anxiety on reading achievement.English language Teaching, 8(7), 206-215. https://www.researchgate.net/publication/281315120_An_Elaboration_on_the_Effect_of_Reading_A nxiety_on_Reading_Achievement

[24].Syokwaa, Sr.K.A., Aloka, P. J.O. \&Ndunge, Sr.N.F. (2016). The relationship between anxiety levels and academic achievement among students in selected secondary Telangana district Kenya.Journal of Educational and Social Research, 4 (3). Doi:10.5901ljesr. 2014.v4n3p403

[25].Amalu, M. N. (2017) .Cognitive test anxiety a predictor of academic achievement among secondary school student in makurdi metropolis, Benue state. International Journal of Scientific Research in Education, 10 362-372. https://www.researchgate.net/publication/331865056_Cognitive_Test_Anxiety_as_a_Predictor_of_A cademic_Achievement_among_Secondary_School_Students_in_Makurdi_Metropolis_Benue_State

[26].Rehman, A. (2010).Academic anxiety among higher education students of India causes and preventive measures: an exploratory study. International Journal of Modern Social Sciences, 5 (2), 106-116.

[27]. Arul, Mr. A.S (2014). Relationship between study habits and test anxiety of higher secondary students. International Journal of Teacher Educational Research, 3(6), 1-9. 
https://www.researchgate.net/publication/262774182_RELATIONSHIP_BETWEEN_STUDY_HAB ITS_AND_TEST_ANXIETY_OF_HIGHER_SECONDARY_STUDENTS

[28].Reyes, M.D.\&Castillo, A.C, (2015). Test anxiety and college students` performance on mathematics department examination: basis for mathematics achievement enhancement. Asia Pacific Journal of Education, Arts and Sciences, 2(1), http://research.lpubatangas.edu.ph/wpcontent/uploads/2015/04/APJEAS-2.10-Test-Anxiety-and-College-Students\%E2\%80\%99-

Performance-on-Mathematics.pdf

[29].Zafar, S. (2010). The effects of anxiety in cognitive processing in English language learning. English Language Teaching,

$3(2)$. https://www.researchgate.net/publication/43941695_The_Effects_of_Anxiety_on_Cognitive_Process ing_in_English_Language_Learning

[30].Hashempour, S.\&, Mehrad, A. (2014). The effect of anxiety and emotional intelligence on the students learning process. Journal of Education Social Policy, 1(2), 115-121. http://jespnet.com/journals/Vol_1_No_2_December_2014/16.pdf

[31].Cassady, J.C. (2004). The influence of cognitive test anxiety across the learning testing cycle. 569592. doi:10.1016/j:learninstruc.2004.09.002 